\title{
SOCIALISMO, MODERNIDADE E IDENTIDADE REGIONAL EM MARIÁTEGUI, SENGHOR E NKRUMAH*
}

\section{Fabrício Cardoso de Mello}

Universidade do Estado do Rio de Janeiro (Uerj), Rio de Janeiro - RJ. E-mail: fcmello@gmail.com

DOI: $10.17666 / 319213 / 2016$

\section{Introdução}

Se os aportes libertários do socialismo foram fundamentais para a paulatina conquista de direitos pelos trabalhadores na Europa, sua influência não se limitou de forma alguma àquele continente. Nas regióes coloniais onde a Europa estendeu seus domínios político-econômicos, a inspiração socialista também esteve presente em movimentos que buscavam algum tipo de emancipação contra regimes tiranos, fossem eles perpetrados pelos próprios europeus, fossem por eli-

* Durante a elaboração do artigo, o autor era bolsista de Doutorado Nota 10 da Faperj, a qual agradeço pelo apoio recebido. Agradeço também à leitura e aos comentários de José Maurício Domingues, Breno Bringel e Fabrício Pereira da Silva, assumindo toda a responsabilidade pelo conteúdo apresentado.

Aprovado em 03/03/2016 tes locais formadas direta ou indiretamente pela administração colonial.

Foi esse o quadro enfrentado pelos autores que figuram neste trabalho. José Carlos Mariátegui (Peru), Léopold Sédar Senghor (Senegal) e Kwame Nkrumah (Gana) se apropriaram do socialismo como via política para a construção de novas sociedades que superassem os malefícios do colonialismo ou, no caso do primeiro, de seu legado póstumo. Imbuídas nessa tarefa estavam reelaboraçóes criativas do socialismo, adaptadas às realidades sociais $\mathrm{da}$ América Andina e da África que, como veremos, foram distintas entre si. Mariátegui, um dos principais intelectuais da esquerda na América Latina, irá propor uma síntese inovadora entre o marxismo e as tradiçóes indígenas andinas, que será consagrada como principal expressão teórica da primeira fase desse movimento político no subcontinente (Löwy, 1999 , p. 9). A essa abordagem, o próprio autor deu o nome de socialismo indo-americano. Senghor e 
Nkrumah estiveram ambos envolvidos com a política de libertação africana e se tornaram, logo após a independência, os primeiros presidentes de seus países. A divergência entre seus pensamentos espelha a pluralidade com a qual o socialismo foi refletido desde a África (Charles, 1965; Mohan, 1966). $\mathrm{O}$ primeiro o interpretava como uma propriedade cultural da civilização africana, enquanto, para o segundo, tratava-se de um caminho para a unificação política continental.

Ao traçar paralelos e apresentar pontos de desacordo, o objetivo deste trabalho é realizar uma comparação entre esses três autores, com o argumento de que suas posiçóes enquanto intelectuais engajados na periferia global levaram-nos a enfrentar desafios teóricos e políticos bastante próximos. $\mathrm{O}$ primeiro deles foi a recriação da concepção de socialismo a partir de contextos sociais náo industriais, o que impôs tarefas específicas quanto aos meios de construção de seus movimentos políticos. Subjacentes, mas consubstanciadas à primeira questão, estão outras duas. Há também nos três autores um projeto de interpretação da modernidade que visa incorporar elementos societários pré-coloniais como fatores necessários a um futuro emancipatório. Por fim, todos se dedicaram igualmente a pensar diferentes alternativas de integração regional que servissem de eixo comunitário em um horizonte pós-colonial. O texto dedica uma seção a cada um desses três objetos de reflexão, identificando-os como pontos fundamentais nas obras dos autores analisados.

\section{Socialismo como opção}

Embora o marxismo fosse dotado de um escopo universal com relação ao seu fim último, ou seja, a construçáo do comunismo sobre os escombros da sociedade burguesa, não foi sem dificuldades práticas e teóricas que se transpôs para contextos sociais não europeus. Em sociedades eminentemente agrárias, nas quais o contingente do proletariado era sobremaneira reduzido para cumprir sua missão de liderança histórica, tal como defendido no $\mathrm{Ma}$ nifesto (Marx e Engels, 1998 [1848]), os caminhos da revolução seriam, no mínimo, incertos. A prin- cípio, esse seria o dilema vivido pelas sociedades latino-americanas e africanas que, de maneira geral, tiveram seu desenvolvimento econômico obstaculizado por políticas compulsórias de exportação de matérias-primas para as metrópoles. Mesmo com configuraçóes históricas e culturais muito diferentes, até mesmo no que diz respeito aos períodos de colonialismo e processos de independência, as duas regiōes ocuparam posiçôes periféricas semelhantes quanto à modernidade industrial europeia.

Os três autores que figuram neste trabalho partilharam, a partir do envolvimento direto na vida política, a procura por uma alternativa ao eurocentrismo (proeminente, em especial, na II e III Internacionais) na construção de vias socialistas recriadas a partir das vicissitudes históricas de suas sociedades. Tratava-se, segundo Löwy (1999), do desafio da definição da "natureza da revolução" específica de cada contexto social, embora nem todos tenham aceitado a opção revolucionária - ao menos em seu formato bolchevique - como algo evidente. $\mathrm{Na}$ verdade, como veremos, cada autor elaborou uma abordagem muito própria do socialismo para dar conta dos elementos históricos e culturais que faziam parte de seu universo - mesmo Senghor e Nkrumah, que enfrentaram desafios políticos muito próximos. Para entender essas diferenças, é necessário analisar a maneira como cada um deles articulou a sua militância ao socialismo, como ideologia política e como inspiração teórica.

Evidentemente, as diferenças começam pelos momentos políticos que o Peru - e, em grande medida, a América Latina - e a África passavam durante a elaboraçáo do pensamento de cada autor. A breve vida intelectual e militante de Mariátegui, encerrada por sua prematura morte em 1930, teve como período mais profícuo a década de 1920 , marcada pelo centenário da independência peruana. Àquela altura, o país ainda lidava com a herança econômica deixada pelo colonialismo, que, por meio da mita e da encomienda, explorou compulsoriamente a mão de obra indígena na mineração e na agricultura. Os indígenas assistiram à inauguração da República sem receber qualquer benefício político, uma vez que a elite criolla ${ }^{1}$ ascendeu ao poder, cristalizando-se na forma de uma oligarquia agrária. É dentro desse quadro que Mariátegui assume 
em 1918 sua orientação socialista, tomando parte, como jornalista, na imprensa de esquerda peruana.

Durante uma estadia forçada na Europa entre 1919-1923, ${ }^{2}$ o intelectual peruano travou contato com os grupos revolucionários e com os trabalhos de uma série de intelectuais europeus da época. Dessa forma, conheceu os círculos proletários de Paris, vivenciou a greve geral de Turim em 1920 e teve acesso à obra de autores como Croce, Unamuno, Simmel e Sorel, cujas publicaçóes não chegavam facilmente a Lima (Miller, 2008, cap. 5). Voltando ao Peru, Mariátegui verteu essas influências em uma abordagem heterodoxa, antirracionalista do marxismo, na firme convicção de que "o marxismo, onde se mostrou revolucionário, [...] nunca obedeceu a um determinismo passivo e rígido" (Mariátegui, 2005 [1959], p. 212). Aplicada ao caso peruano, tal perspectiva acabou por eleger o indígena, que compunha três quartos da população, como o protagonista da transformação social. $\mathrm{O}$ incipiente proletariado nacional tomaria parte no processo, mas não tinha a musculatura necessária para liderá-lo.

As trajetórias intelectuais e políticas de Senghor e Nkrumah têm início na África ainda sob jugo colonial, quando retornam de suas jornadas fora do continente na década de $1940,{ }^{3}$ o que faz com que o primeiro problema a ser resolvido seja o da independência. $\mathrm{O}$ socialismo de Nkrumah tem raiz em seu projeto de emancipação continental na forma de uma união pan-africana. Durante o processo de independência da Costa do Ouro, ele funda o Convention People's Party (CPP), em 1949, para se opor à política de libertação gradualista da colônia de outras organizaçôes. Com o lema "autogoverno já”, Nkrumah enxergava a necessidade de tornar o CPP um partido de massas, junto a qual deveria exercer o papel de orientador na libertação. A influência das teses de Lênin sobre a centralidade do partido na organizaçáo socialista é presente ao longo de todo o livro Africa Must Unite (1963), em que Nkrumah apresenta o programa de construção nacional de Gana - independente em 1957 - e afirma a necessidade do socialismo para uma futura integraçáo de todos os Estados africanos. ${ }^{4}$ As elites africanas são vistas por ele como agentes indiretos do imperialismo e inimigas das massas, mas o combate a elas só seria possível por meio da diligência do partido.

As atuaçóes e reflexóes políticas de Senghor são indissociáveis de sua carreira como escritor e poeta, especialmente pelo seu envolvimento com o movimento Négritude, fundado por ele junto com o antilhano Aimé Cesaire. Ambos defendiam a celebração da manifestação cultural de uma $c i$ vilização negro-africana que, apesar de espalhada por todo o continente - e também fora dele, devido às sucessivas diásporas - partilhavam uma mesma matriz. O socialismo seria uma opção política evidente para a independência, porquanto existiria nele uma afinidade natural com a tradição comunitarista africana. A relação de Senghor com o marxismo, no entanto, é mais problemática. $\mathrm{O}$ "materialismo ateu" do Marx pós-1848 seria incompatível com o espírito africano, religioso por essência e, por causa disso, Senghor se identificava mais com seus trabalhos prévios, nos quais o idealismo é mais saliente (Senghor, 1961 [1960]).

É possível indicar um primeiro desacordo entre os autores com relaçáo às interpretaçóes que fazem de suas sociedades. A situação político-econômica africana era dominada pelas forças imperialistas, que mantinham junto a si pequenas elites autóctones para servir como intermediárias entre a administração colonial e as massas. Em sociedades predominantemente agrárias, esses grupos se caracterizavam pela inserção privilegiada na economia - eram, em geral, funcionários administrativos, comerciantes e profissionais liberais -, pela habitação urbana e, principalmente, pela sua formação dentro de padróes educacionais europeus. No entanto, ambos os autores (no caso de Nkrumah, ao menos no primeiro momento de sua obra, ver itens seguintes), assim como vários pensadores africanos da época, consideravam que essa elite era fruto de uma estratificação excessivamente primária para dar corpo a um conflito de classes plenamente desenvolvido (Mohan, 1966, p. 239). Aqui há uma diferença fundamental com relação a Mariátegui, para quem a proeminência criolla era o reflexo direto do papel dependente do Peru da economia capitalista mundial e só poderia ser derrubada por uma aliança classista entre campesinato indígena e proletariado. 
Essas duas leituras sobre a questáo de classe incorrerão em distintas concepçóes sobre o partido. Os três autores enxergam nesse tipo de organizaçáo um ator central no processo de transformação e na coordenação da construção de uma nova sociedade. Contudo, para Mariátegui, que fundou o Partido Socialista Peruano (PSP) em 1928, a base e o papel do partido eram muito claras: tratava-se de uma coletividade camponesa e operária, voltada a um movimento revolucionário cujo fim era o estabelecimento da ordem socialista liderada por trabalhadores (Mariátegui, 2005 [1928a]). Mas, para Senghor (1961 [1959]; [1960]) e Nkrumah (1963), o principal antagonista da luta popular era o colonialismo, o que lhes permitia generalizar ao máximo as suas orientações. $\mathrm{O}$ partido acaba sendo o representante da vaga noção de "massas", que engloba praticamente todos aqueles que não fazem parte ou não estão ligados diretamente ao aparato colonial. Isso dá às duas versōes sobre o socialismo africano um tom eminentemente nacionalista, cuja prioridade era a formação de uma identidade homogênea oposta à dominação imperialista estrangeira.

Expostos os princípios, é preciso verificar como cada um traça os contornos finais de seus projetos. Mariátegui localiza o problema do Peru no regime de propriedade da terra e nas relaçóes de produçáo dele decorrentes. No país, segundo ele, três economias diferentes coexistiam, e a relação entre elas era a chave para entrever o caminho da revolução (2008 [1928], p. 46). A elite agrária herdara dos espanhóis o empreendimento latifundiário baseado na utilização da mão de obra indígena em um regime muito semelhante à servidão. $\mathrm{O}$ desenvolvimento atrofiado da burguesia se deu de tal forma por estar subjacente ao gamonalismo, ${ }^{5}$ que optou pela economia de exportaçóes de matérias-primas para o centro capitalista - primeiro a Inglaterra e depois os Estados Unidos. A esperança estava nos resquícios dos laços solidários indígenas presentes nas terras altas peruanas que, acredita Mariátegui, eram descendentes do comunismo incaico. $\mathrm{O}$ autor afirma que a civilização inca tinha como célula básica as ayllu, comunidades rurais cuja propriedade coletiva da terra incitava à cooperação igualitária, conferindo-lhe superioridade moral sobre o feudalismo criollo e seu rastro de servidão (2008
[1928], cap. 3). Esse tipo de comunismo agrário seria superior também economicamente, já que sua eficácia produtiva teria sido suficiente para garantir o bem-estar material de todo o antigo império. O "romantismo revolucionário" de Mariátegui (Löwy, 2005) lhe permitia se desviar criativamente do dogmatismo para defender seu socialismo indo-americano, que, em termos programáticos, foi explicitado em um polêmico texto apresentado em 1929 durante a Primeira Conferência Comunista Latino-Americana, organizada pelo Comintern. Nele, Mariátegui declara que a revolução peruana viria com a reforma agrária radical, por meio da qual as terras dos latifúndios seriam desapropriadas para o estabelecimento de comunidades inspiradas nas ayllu. Dado esse passo, a adaptação das comunidades para a vida moderna na forma de cooperativas agrárias se mostraria bastante verossímil (2006 [1929a], pp. 40-43).

Para Mariátegui, a associação entre o socialismo e a tradição indígena tinha uma justificativa econômica. Dizia ele que não havia chegado a tal ideia "pelo caminho da erudição livresca, da intuição estética ou mesmo da especulação teórica, mas pelo caminho - simultaneamente intelectual, sentimental e prático - do socialismo" (2005 [1927a], p. 109). O mesmo não pode ser dito de Senghor, que buscou uma articulação parecida, partindo, contudo, de outros princípios. Se a estética foi recusada como motivação pelo peruano, sem dúvida ela foi um dos principais pilares da concepçáo socialista do senegalês. Católico, Senghor recebeu a influência do pensamento holista do padre jesuíta e filósofo Teilhard de Chardin, cujo conceito de Civilização do universal foi absorvido como meio para construção de um "humanismo do século XX" (Diagne, 2007, p. 33). A partir de tal aporte, Senghor afirmava que "cada povo, cada raça, cada continente cultiva, com dileçóes particulares, certas virtudes do homem, no que reside precisamente a sua originalidade" (Senghor, 1956, p. 65). Cada cultura, portanto, contribuiria com sua particularidade para uma comunidade pan-humana e o grande mal do colonialismo havia sido justamente a deturpaçáo da cultura negro-africana, conduzindo-a ao progressivo empobrecimento. Senghor lançava um convite à valorização dessa cultura, baseada numa racionali- 
dade intuitiva, e não analítica, como a do europeu, e que se expressava fundamentalmente por meio da arte e da literatura. Dessa forma, concluía ele, "a independência de espírito, a independência cultural, é previamente necessária às outras independências: política, econômica e social" (1961 [1960], p. 95; grifo do autor).

A exortação à cultura negro-africana fez Senghor buscar nela a necessidade do socialismo como via política para a África pós-colonial: “[...] a sociedade negro-africana é uma sociedade coletivista, mais exatamente comunitária [...] nós já havíamos realizado o socialismo antes da chegada europeia. Concluímos que temos a vocação para renová-lo ajudando a lhe restituir suas dimensóes espirituais" (1961 [1959], p. 71; grifo do autor). O socialismo africano, segundo o autor, estava já presente num tipo de organização social horizontal e igualitária que predominava no continente antes da dominação colonial, e o passo necessário para resgatá-lo seria um processo de renascimento cultural empreendido por um partido comprometido com a causa negro-africana (1961 [1959]). ${ }^{6}$ O principal elemento negativo do capitalismo, o individualismo, seria combatido dessa maneira, o que implicava a ausência de um conflito econômico no contexto africano: a alienação vivenciada era proveniente do racismo, da dominação de um grupo étnico sobre outro (1961 [1960], p. 106).

A questão da prioridade da independência sempre foi o principal ponto de desacordo entre Senghor e Nkrumah. Se o primeiro escolhia a via cultural, o segundo defendia que a única forma de libertar a África era cortar imediatamente os laços políticos com a metrópole. Em Africa must unite, encontramos um panorama de sua luta anticolonial, partindo da análise da independência de Gana até seu projeto de uniáo continental. Nele, Nkrumah narra como o CPP estava promovendo a planificação da economia nacional e assumindo a responsabilidade de, no longo prazo, transferir para "as mãos do povo os principais meios de produção e distribuição" (1963, p. 120). A ausência do conflito de classes em Gana, tese defendida em seu livro Conciencism (1970 [1964]), fazia do CPP o protagonista do processo de construção socialista, uma vez que era o único representante dos interesses de toda a nação. Para Nkrumah, seu partido era a tradução da teoria marxista nos termos práticos do contexto africano: "A estrutura do CPP foi construída de nossa própria experiência, condição e ambiente. Ela é inteiramente ganense em conteúdo e africana em aparência, embora imbuída da filosofia socialista marxista" (1963, p. 129). No entanto, a forma como ele combina o diagnóstico de ausência de classes com a centralidade partidária na direção da sociedade, distancia-o da clássica via revolucionária de Marx, uma vez que a própria revolução seria algo dispensável às sociedades africanas. Para o pensador, levando em conta que "o espírito do comunalismo ain$\mathrm{da}$ existe em certo grau nas sociedades com um passado comunalista, socialismo e comunismo não são crenças propriamente 'revolucionárias"” (1970 [1964], p. 74). Ou seja, a instauração do socialismo na África não seria resultado de uma ação revolucionária de vanguarda, mas da ação de uma reapresentação dos princípios comunitários africanos por meio da atuação vertical do partido, incumbido da formação ideológica e da coordenação de quadros junto à população.

Em fase posterior, refletindo sobre as dinâmicas do neocolonialismo em um continente formalmente independente, Nkrumah reavaliará o papel da luta revolucionária na África, que passará a ser vista como única via concreta de emancipação do sistema global capitalista. A distinção de diferentes momentos em sua obra será retomada nos itens seguintes. Cumpre, neste instante, diferenciar seu projeto de restauração do defendido por Senghor. O resgate de um socialismo pré-colonial estava, para Nkrumah, justificado pela necessidade de uma base social e política para uma integração africana que levasse a cabo o processo de independência junto às metrópoles. Se ele não propunha, ao menos de início, uma ideia de revolução fundada no conflito de classes, todo seu projeto estava fincado em uma ação de ruptura, anticolonial e anti-imperialista. À diferença do senegalês, Nkrumah assinalava um caminho de emancipação política de facto como condição necessária para o pleno desenvolvimento de sua concepção de socialismo. 


\section{Modernidade e trajetórias locais}

A realizaçáo de leituras socialistas sobre as sociedades africanas e latino-americanas levava a um desafio conceitualmente mais geral aos autores, o de lidar com o tema da modernidade. Na América Latina, as lutas por independência foram animadas por um forte espírito emancipatório liberal inspirado no pensamento iluminista. No entanto, como já visto aqui, as forças que lideraram o processo negaram aos indígenas e demais camadas populares a concretização dos principais valores da modernidade - notadamente a liberdade e a igualdade - fundando governos nacionais conservadores e elitistas (Domingues, 2009, cap. 1). Na África, a experiência da modernidade como um projeto social real foi coordenada pelo colonialismo europeu até meados do século XX. Durante o período, entretanto, as mesmas autoridades que levaram aos africanos promessas de emancipação e progresso se esforçaram por não concretizá-las (Macamo, 2005, pp. 4-8).

Esse tipo de dilema foi largamente analisado sob a ótica da assim chamada "teoria da modernização", muito popular entre as décadas de 1950-70 em estudos sobre sociedades "periféricas" ou "subdesenvolvidas". Suas teses, elaboradas tanto por autores liberais quanto marxistas, apontavam para um caminho único do desenvolvimento moderno, que deveria necessariamente repetir as conquistas do processo histórico ocorrido na Europa a partir do século XIX. Dentro desse índice escalar evolutivo, a persistência da tradição é identificada com a imagem do atraso. A aplicação da perspectiva às sociedades africanas e latino-americanas resultou, invariavelmente, no diagnóstico do fracasso, muitas vezes atribuído a particularidades intrínsecas das culturas locais. Dessa forma, Lipset (1967) trabalha a tese de que a América Latina se encaixaria no modelo particularista-adscritivo parsoniano, cujo padrão valorativo impulsionaria o subcontinente ao retardo político, econômico e intelectual. Para Mohan, o mesmo ocorreria na África, onde "o 'indivíduo' ainda está para emergir da matriz social da qual ele forma parte orgânica", sendo a preeminência de laços comunitários o motivo para que "exista nos novos Estados um mau uso pessoal ou privado do poder político e dos fundos públicos" (1966, p. 233).
Nas obras dos autores analisados, encontramos características que destoam da interpretaçáo fortemente eurocêntrica da teoria da modernizaçáo. A construção de socialismos atentos às especificidades das realidades africanas e peruanas representava, junto ao alvo político imediato, um esforço para lidar com a configuração moderna ambivalente que havia se desenvolvido nas duas regióes. Os três assumiram um compromisso de transformaçáo social que proporcionasse às massas a possibilidade de uma experiência positiva da modernidade, para além da dominaçấo e da desigualdade vigentes. Isso foi buscado por eles em interpretaçóes que não se fiavam em rotulaçóes externas desabilitadoras, mas que trilhavam caminhos próprios para pensar de maneira afirmativa as configuraçōes particulares da modernidade em suas sociedades. Isso implicou projetos de modernidade que a articulassem com as heranças comunitárias que haviam persistido mesmo com o avanço do colonialismo.

Mariátegui é o autor que explora esse intento mais a fundo, construindo sua análise revolucionária do caso peruano sobre os pilares de um engajamento entre a modernidade ocidental e elementos societários indígenas. Esse projeto nasce de uma visão otimista sobre as possibilidades abertas pela modernidade, que o levavam a imaginar um futuro que superasse a passagem necessária pela mesma trajetória europeia:

Ele retratava o mundo moderno como um espetáculo permanentemente fascinante, repleto de potencial dramático para triunfar sobre as amarras do passado e se reinventar.[...] Para Mariátegui, não era a modernidade em si que causava alienação, uniformidade e desumanização, mas a sua versão capitalista burguesa que passava pela crise na Europa (Miller, 2008, p. 145).

A colonização espanhola haveria trazido ao Peru um padrão econômico feudal inferior às relaçôes econômicas socialistas presentes na civilização inca. A soluçấo encontrada por Mariátegui é o processo revolucionário, descrito no item anterior, que se esforçava em desviar de uma visão determinista do avanço histórico em favor de uma síntese criativa entre o que considerava o tradicional e o mo- 
derno. É importante ter em mente que Mariátegui diferenciava uma tradição "viva e móvel", apta à recriação revolucionária, dos incas do tradicionalismo gamonalista, inerte, recrudescido na forma de uma postura política conservadora e avessa a mudanças (2005 [1927b]; [1927c]). O autor procurava também se distanciar de visóes essencialistas sobre o indígena, presentes nas teses de autores liberais que propunham a existência de uma tensão entre o "nacional" e o "exótico" no Peru (2005 [1924a]). Esse tipo de assertiva engessaria o potencial transformador da herança inca nos mesmos moldes do tradicionalismo hermético gamonalista.

Assim, fica claro que a proposta de Mariátegui não é uma espécie de volta ao passado, do restabelecimento tout court do socialismo incaico. Sua preocupação em deixar isso evidente se encontra quando ele nos fala da susceptibilidade das comunidades agrárias indígenas a se atualizarem no tempo presente. Valendo-se da descrição de um funcionário do governo peruano, e adotando um discurso que denota fortes traços de uma concepção industrial da modernidade, Mariátegui indica a adaptação das comunidades aos padróes técnicos do trabalho moderno e afirma: "a comunidade, com efeito, quando se articulou com a passagem de uma linha férrea, com o sistema comercial e as vias de transporte centrais, chegou a se transformar espontaneamente em uma cooperativa” (2008 [1928], p. 97). A grande vantagem, nesse caso, é que a vida nas comunidades não teria absorvido o espírito individualista da sociedade industrial. Uma revolução nos moldes elaborados por Mariátegui traria à luz a possibilidade da experiência moderna pautada por uma organização social coletivista, que ele percebia como a essência incorpórea partilhada pelos socialismos moderno e incaico (2008 [1928], pp. 91-6). $\mathrm{Na}$ passagem a seguir, Mariátegui sintetiza sua visão:

O socialismo não é, certamente, uma doutrina indo-americana. Mas nenhuma doutrina, nenhum sistema contemporâneo não é e nem pode sê-lo. E o socialismo, embora tenha nascido na Europa, tal como o capitalismo, tampouco é específica ou particularmente europeu. É um movimento mundial, a que não se subtrai nenhum dos países que se movem dentro da órbita da civilização ocidental. Esta civilização conduz, com uma força e com meios de que nenhuma civilização dispôs, à universalidade. A Indo-América, nesta ordem mundial, pode e deve ter originalidade e estilo, mas não uma cultura e nem um destino particulares. (2005 [1928b], p. 120)

Há aqui uma "dialética revolucionária entre o passado, o presente e o futuro" (Löwy, 2005, p. 20, grifo do autor), cuja síntese criativa associa o universalismo moderno à herança local do indígena, afirmando que o socialismo na América Latina não pode se dar por uma via exclusiva, nem ser mero "decalque e cópia" de sua versão europeia (Mariátegui, 2005 [1928b], p. 120).

Senghor também não propõe a incompatibilidade entre modernidade e tradição comunitária africana, mas enxerga tal relação a partir da centralidade que confere à cultura na sua obra. $\mathrm{O}$ contexto pós-independência na África liberta deveria ser regido pela força da négritude, entendida como "o conjunto dos valores civilizacionais do mundo negro” (1977 [1966a], p. 90), que, por sua vez, seriam expressos por "uma certa maneira, não europeia, de pensar o mundo e de estar no mundo" (1977 [1970], p. 216). Existiria, para Senghor, uma ontologia tipicamente negro-africana, pautada pela subjetividade e pelo movimento - mais propriamente, pelo ritmo - oposta à matriz objetiva e estática da filosofia greco-romana (1977 [1966b], p. 72), que resultaria, portanto, numa diferença civilizacional entre a Europa e a África. Todavia isso não significaria um conflito inerente entre as duas culturas. Pelo contrário, a construção do socialismo africano não viria com a refutação do europeu, mas com a seleção daqueles valores e objetivos que demonstrassem afinidade com a nação negro-africana (1961, p. 9).

Senghor destaca a técnica moderna europeia sobretudo o "espírito das máquinas" - como algo a ser apreendido pelas sociedades africanas (1977 [1970], p. 216). Em troca, a África ofereceria à Europa e ao mundo todo o dinamismo da négritude que, na realidade, já teria se consagrado como fonte de renovação cultural no Ocidente desde fins do século XIX (1977 [1966b], p. 75). Esse tipo de in- 
tercâmbio se daria dentro da Civilização do universal, irmandade planetária proposta por Teilhard de Chardin, em que cada nação oferece às demais suas características mais valorosas. Estabelecer-se-ia, dessa forma, uma relação de complementaridade entre as civilizaçóes negro-africana e europeia (1977 [1970], p. 241). Se Mariátegui buscou atualizar as tradições coletivistas indígenas no Peru por uma via revolucionária que reinterpretasse a dialética histórica marxista, Senghor tinha um objetivo parecido, mas que seria alcançado por uma espécie de simbiose cultural entre diferentes povos.

Quanto a Nkrumah, sua leitura sobre a modernidade não é a mesma ao longo dos principais momentos de sua obra. É possível encontrar concepçóes distintas sobre o problema, que variam de acordo com a forma como o papel da tradição na África moderna é contemplado. A primeira delas concentra-se em Africa must unite e, em linhas gerais, não se diferencia muito dos programas de desenvolvimento presentes na teoria da modernização. No primeiro capítulo do livro, chegamos a encontrar uma referência ao progresso e à opulência dos principais impérios pré-coloniais africanos, mas, segundo Nkrumah, sua memória não se fazia mais sentir desde a penetração europeia. Em seguida, o autor traça um plano de reestruturação econômica para Gana, que visa alavancar a industrialização do país no período de tempo mais curto possível, e assim "abolir a pobreza, a ignorância, o analfabetismo e melhorar o sistema de saúde" (Idem, p. 118). Além disso, estava incluso no projeto a modernização da agricultura - substituição da prática de subsistência pela produção de commodities - e uma reformulação educacional, visando à criação de mão de obra técnica e especializada para assumir os quadros industriais a serem desenvolvidos no longo prazo.

A ênfase sobre a importância do comunitarismo na África aparece somente em Conciencism (1970 [1964]), trabalho em que Nkrumah pretende elaborar uma ideologia específica para a descolonização e que marca já uma ligeira distinção em relação ao livro de 1963 . Nesse escrito, o autor se volta mais detidamente ao passado africano e afirma que as sociedades pré-coloniais organizavam-se numa matriz coletivista, plenamente igualitária e integrada, sem qualquer tipo de interesses seccionais (Idem, p. 69). A introdução do colonialismo passou a ameaçar esse tipo de estrutura social horizontal, incentivando o desenvolvimento de elites ocidentalizadas, com interesses divergentes da maioria da população. Contudo, Nkrumah se mantém fiel ao diagnóstico realizado outrora sobre a ausência do conflito de classes na África e propóe uma prática político-social para prevenir que esse tipo de estratificação danosa ocorra (Idem, p. 98). Trata-se da edificação de um socialismo africano que reúna as características positivas dos três padróes culturais que se instalaram no continente: o euro-cristão, o islâmico e o africano. Esse último seria fundamental, pois forneceria as bases igualitárias para o novo tipo de sociedade projetado pelo autor.

O esquema básico de Conciencism, por vezes, lembra o encontro civilizacional euro-africano presente no pensamento de Senghor. Não é surpresa que Nkrumah tenha revisado a ideia geral do livro e voltado atrás em alguns de seus argumentos, lançando posteriormente uma segunda edição com diversas alteraçóes no texto original. Segundo Hountodji (1983, p. 134), essa mudança representava a passagem definitiva de um primeiro a um segundo momento da obra de Nkrumah a partir de 1965 , quando o autor teria começado uma reavaliação de seu trabalho, conforme sua preocupação com as trajetórias das independências africanas que vinham então ocorrendo. O ganense teria se dado conta de que a independência formal das antigas colônias não representava necessariamente o fim da heteronomia no continente, que agora se apresentava por meio do neocolonialismo. O forte voluntarismo que marcava seus primeiros escritos, que apontavam para a organização do partido com o fim de mediar um passado comunitarista e um futuro autônomo e cooperativo, dá lugar a uma leitura crítica que recorre à análise de classe e atenua o entusiasmo anterior com o padráo civilizacional das sociedades pré-coloniais africanas.

Em um pequeno texto intitulado African socialism revisited (1967), somos então apresentados a uma nova visão sobre a tradição comunitária africana que destoa daquela oferecida anteriormente. Nkrumah afirma agora que a tese de uma sociedade comunal plenamente igualitária 
e desprovida de hierarquias sociais é idílica, não sendo sustentada por qualquer evidência histórica ou antropológica (Idem, p. 88). Dessa maneira, o socialismo não era um dado espontâneo no continente, mas, sim, algo a ser buscado programaticamente pelos líderes africanos. Isso não impedia que eles se inspirassem nos valores humanistas que de fato permeavam a tradição, não obstante sua convivência com outras características menos virtuosas. Após avaliar os resultados das lutas anticoloniais em seu livro sobre o neocolonialismo de 1965, Nkrumah voltou atrás em seu argumento sobre a inexistência do conflito de classes no continente, passando a vê-lo entáo como o fruto das alianças do imperialismo europeu e estadunidense com diferentes elites nacionais locais, que teriam convertido projetos de emancipação em correias de transmissão do sistema global de dominação capitalista. Nesse momento, ele adere a um horizonte revolucionário, porquanto admite que a saída ao neocolonialismo estava na união das forças anticoloniais restantes numa oposição ao imperialismo estrangeiro e seus representantes locais, em uma jornada que inevitavelmente envolveria a luta armada em dimensôes internacionais (Hountondji, 1983, pp. 135-139). Nesse contexto, a articulação entre modernidade e socialismo em Nkrumah passa por uma reformulação notável. Ainda que um espírito comunitário possa - e em certo sentido, deva - servir de inspiração à busca por autonomia, sua importância é acessória à organização revolucionária anti-imperialista, que ganha particularidade na África devido ao posicionamento periférico do continente no sistema capitalista mundial.

\section{Integração regional e identidade}

Outro fator de relevante comparação é o exercício de construção de identidades nacionais e regionais, elemento que, de uma forma ou de outra, se encontra nos três autores em análise. Se, como foi dito aqui, suas concepçóes socialistas orientavam os esforços de interpretação para a transformação das realidades locais africana e peruana, traziam consigo a missão de oferecer às respectivas populações novos marcos de referência para a construção de sentidos de comunidade distintos daqueles impostos pela colonização. Para Mariátegui, a integração nacional seguia, nos anos 1920, como um dos desafios não cumpridos pela República, após mais de cem anos da independência peruana. Para Senghor e Nkrumah, esse problema era um dos mais urgentes a ser resolvido na África pós-colonial, o que não implicava a concordância quanto aos meios.

Para averiguar como cada autor enfrenta a questáo é interessante pensar contra quem eles direcionaram seus projetos de mudança social. Talvez, nesse sentido, a obra de Nkrumah tenha sido a mais incisiva, haja vista o ganense ter dedicado todo um livro para analisar aquilo que considerava o maior obstáculo da emancipação africana: o neocolonialismo. Este teria sido resultado da crescente infiltração de grupos capitalistas europeus, associados ao capital financeiro dos EUA, nos países africanos recém-libertos, sem a necessidade da ocupação territorial de outrora (1967 [1965]).

Destarte, a colaboração econômica com as antigas metrópoles era vista, no mínimo, com grande desconfiança por Nkrumah. Sua opinião sobre a aliança dos novos países que antes faziam parte da África Ocidental Francesa (AOF) - entre eles, o Senegal de Senghor - com a Comunidade Francesa, ${ }^{7}$ na forma de programas de "auxílio ao desenvolvimento econômico", era taxativa: eles estavam se tornando "[...] Estados clientes, independentes no nome, mas que eram, na realidade, peóes do mesmo poder colonial que supostamente lhes deu independência” (1963, pp. 174-175). Nesse caminho, suas economias continuariam dependentes, perpetuando o sistema de fornecimento de matérias-primas para Paris e a atrofia da indústria nacional. A quebra das regióes da África Ocidental e Equatorial sob domínio francês em entidades diferentes significava, segundo ele, "a balcanização em prática [o que] reforçou as ambiçóes de personalidades políticas, aprofundando desentendimentos que estavam a caminho de serem resolvidos" (1963, p. 178). Em uma palavra, a França teria percebido a insustentabilidade de seu aparato colonial, mas não abriria mão da hegemonia sobre a região, impedindo a unificação política das ex-colônias e seu desenvolvimento econômico autônomo. 
Adotando essa postura, Nkrumah se opunha frontalmente ao posicionamento de Senghor, cujo papel como liderança política na adesão africana à Comunidade Francesa foi de grande destaque. Senghor sempre esteve mais próximo da política metropolitana do que Nkumah, tendo participado por duas vezes do parlamento francês como deputado d'além-mar. Porém, isso não significava que ele se opusesse à libertação. A fundamentação para a independência oferecida por ele era justamente uma autocrítica à participação africana na vida política francesa - fosse na atuação de representantes das colônias no parlamento, fosse na aliança com partidos operários franceses, como o Section Française de l'Internationale Ouvrière (SFIO). Dizia Senghor que "os partidos franceses, mesmo os de esquerda, eram partidos nacionais, informados pelas realidades nacionais e voltados aos interesses nacionais" $\mathrm{e}$ isso os impossibilitava de compreender as demandas das colônias, "nem a situação, nem as necessidades e nem os valores negro-africanos e malgaxes" (1961, p. 8). As organizaçōes políticas africanas deveriam se voltar para os dilemas de suas próprias sociedades e, no entendimento de Senghor, a independência era o caminho necessário para a reestruturação da cultura e dos valores negro-africanos.

Mas à independência era imprescindível a assistência da antiga metrópole, pois, acredita o autor, abandonar as ligaçóes com a Europa significaria renunciar às chances de progresso técnico abertas aos novos países a partir de uma aliança com a França. $\mathrm{O}$ projeto político que nasce daí é a construção de unióes de Estados por similaridades regionais e culturais, testado na prática no ano de 1959 com a criação da Federação do Mali. Tratava-se de um acordo entre o Senegal e o Sudão Francês, que se uniriam enquanto um "Estado federal, ou melhor, uma nação negro-africana, livremente associada à França numa Confederação" (1961 [1959], p. 15). Cada um dos Estados-membros teria direitos iguais e ampla autonomia, conferindo ao governo central somente as decisóes políticas mais gerais, estritamente definidas e limitadas (Idem, p. 24). Além disso, o objetivo era que, no futuro próximo, os demais países da $\mathrm{AOF}$ se juntassem à federação, pois formavam uma só comunidade "negro-berbere", cujo destino havia sido entrelaçado definitivamente pelo colonialismo francês. A concepção de nação, para Senghor, tinha base estritamente cultural e buscava unir povos que, segundo ele, compartilhavam semelhantes "clima, sol e sangue, línguas e costumes, arte e literatura" (Idem, p. 26). Em agosto de 1960 , no entanto, a união foi frustrada, pois os deputados senegaleses aprovaram seu desligamento da federação.

Tal projeto desviava totalmente das expectativas de Nkrumah. Para ele, o continente como um todo, apesar de toda a pluralidade étnica e linguística, deveria formar uma só nação integrada política e economicamente, o que se tornaria realidade com a progressiva fusão dos microestados num governo centralizado pan-africano. A independência de Gana em 1957 seria apenas o primeiro passo para a construção dos Estados Unidos da África, uma federação multicultural a ser formada com inspiração nas constituições dos Estados Unidos e da Uniāo Soviética e que, embora socialista, não iria se alinhar a nenhum dos polos da Guerra Fria. O resultado seria o progresso econômico, que traria bem-estar para toda a população continental e permitiria que a África fizesse frente às grandes potências mundiais (1963, pp. 163-164). O ambicioso projeto tinha origem na cruzada anti-imperialista que Nkrumah considerava necessária para o fortalecimento da região, prejudicada imensamente pelo legado colonial.

Diante da resistência de certos países que julgava cooptados pelas antigas metrópoles, Nkrumah deixou de lado a projeção dos Estados Unidos da África na fase posterior de sua produção intelectual, que, como assinalado anteriormente, assume tom crescentemente revolucionário. Há nesse processo a mudança de uma visão eminentemente estadista e institucional sobre a constituição de uma identidade africana para outra fenomenologicamente militante, isto é, que enxerga a identidade como algo delineado no ensejo da luta. Sua concepção de comunidade africana é então redimensionada e atrelada ao desafio de oposição ao neocolonialismo, contemplando "os vários movimentos de libertação lutando em diferentes territórios ao invés de tentativas pouco realistas de formar um governo continental (Hountondji, 1983, pp. 138-139).

Com relação à obra de Mariátegui, também encontramos uma tensão referente ao problema 
do imperialismo, decorrente, principalmente, de sua rivalidade política com Victor Raul Haya de la Torre. Tratava-se de um antigo companheiro de militância, com quem o peruano rompeu em meados da década de 1920, que também foi fundador do Alianza Popular Revolucionaria Americana (Apra). Haya de la Torre partia igualmente de uma crítica às oligarquias agrárias, mas ignorava o potencial revolucionário do campesinato indígena - e do proletariado unido a ele - que Mariátegui sublinhava. Essas elites seriam as principais aliadas do imperialismo estadunidense e facilitariam sua atuação em toda América Latina, ou Indo-américa, como Haya de la Torre se referia ao subcontinente. Seu aprismo defendia, portanto, uma luta anti-imperialista a ser empreendida por meio de uma aliança entre camponeses, proletariado, intelectuais e burguesia. A participação dos dois últimos grupos na frente ampla era fundamental, pois o progresso econômico das classes médias seria um dos primeiros fatores a serem freados pela barreira imperialista (Haya de la Torre, 1986 [1936], pp. 29-30), e, além disso, as massas trabalhadoras seriam demasiadamente "ignorantes" para liderar tal projeto político (Idem, pp. 33-4).

Para Mariátegui, a mirada anti-imperialista de Haya de la Torre desviava a análise do real problema peruano, aliviando a responsabilidade das elites agrárias no atraso econômico do país e mascarando o conflito de classes existente. Esse último ponto era crítico para Mariátegui, pois a aliança de classes proposta pelo aprismo representaria a sujeição derradeira dos trabalhadores rurais e industriais peruanos. Dizia ele que "a revolução socialista encontraria seu mais amargo e perigoso inimigo - perigoso por sua indefinição, sua demagogia - na pequena burguesia afirmada no poder [...]" e que o exemplo histórico que negava o papel anti-imperialista da burguesia era sua ligação no México pós-revolucionário com o "imperialismo yanqui" (2006 [1929b], pp. 86-87). A única aliança revolucionária no Peru era a aliança socialista entre o campesinato e o proletariado, que deveria, por sua vez, orientar-se numa ação concertada contra a oligarquia nacional, um inimigo imediato e concreto.

Mariátegui acreditava que o tipo de integração total latino-americana, defendida por seu antigo companheiro, havia se esgotado após as lutas por independência, e que, naquele momento, os países latino-americanos formavam uma comunidade dispersa e fragmentada. As próprias unidades nacionais encontrar-se-iam mal formadas e pouco integradas entre si, e, somando isso à ausência de cooperaçáo econômica entre elas, a ideia de unidade latino-americana se mostrava pouco palpável naquele momento (Mariátegui, 2005 [1924b], p. 81). Sua prioridade seria dar continuidade à construçáo da nação no Peru, um horizonte que só poderia ser alcançado com a integração plena do campesinato indígena à sociedade: "uma política realmente nacional não pode prescindir do índio, não pode ignorar o índio. O índio é o alicerce da nossa nacionalidade em formação" (Mariátegui, 2005 [1924c], p. 87). A evidente soluçáo para o problema viria com a revolução indo-americana descrita acima, quando finalmente a parcela majoritária da população estivesse livre da dominaçáo gamonalista.

No curso da tarefa de imaginar comunidades, como diria Anderson (2008 [1991]), as fronteiras estabelecidas pelos nossos três autores e os caminhos que encontraram para alcançar a soberania indicam a natureza das concepçóes políticas de cada um. Senghor e Nkrumah lidavam com um tipo de dominação externa comum, mas enquanto o primeiro a enxergava como uma forma de sujeição cultural, o segundo a via como a raiz da pauperização material e moral de todo o continente. $\mathrm{O}$ alcance dos projetos nacionais de cada autor acabou proporcional ao seu diagnóstico. Senghor buscou a via da independência na esperança de formar uma comunidade regional francófona, com relativa proximidade à antiga metrópole, enquanto Nkrumah lutou por uma união africana que contestasse alianças políticas e econômicas com a Europa. Dos três, Mariátegui foi o único que se concentrou de fato dentro das fronteiras clássicas do Estado-nação, o que, a meu ver, se dá por um motivo fundamental. A ideia de uma unidade latino-americana ainda era vista pelo autor como associada às campanhas por independência desenroladas no início do século XIX, quando houve uma forte valorização da identidade criolla. No Peru, e em toda a região andina, a proeminência criolla na pós-independência veio acompanhada da exclusão social do índio. Em vista 
disso, Mariátegui entendia que primeiro era preciso haver um processo de recriação das nações latino-americanas, para que qualquer tipo de projeto de unidade fosse aventado.

\section{Conclusão}

A discussão desenvolvida neste artigo se relaciona de certo modo a um esforço de investigação que busca aproximar comparativamente a produção intelectual de pensadores políticos e sociais fora do eixo Europa-Estados Unidos, com foco na América Latina e na África. O trabalho que Devés-Valdés (2008) vem realizando nos últimos anos representa a versão mais sistemática nesse sentido, mas é importante reconhecer que ainda há muito a ser explorado neste quadro de pesquisa. A comparação aqui apresentada deve ser estendida, em futuros trabalhos, a outros autores além dos três sobre os quais nos debruçamos, o que potencialmente ampliará a compreensão sobre as vicissitudes do pensamento político na periferia global. Ademais, é importante salientar que questóes internas à comparação dos pensamentos de Mariátegui, Senghor e Nkrumah devem igualmente receber contínua atenção. Devido à limitação de espaço, privilegiou-se um trabalho que abordasse o que pensamos ser os pontos comuns fundamentais entre os autores. Futuras análises podem vir a explorar outras questóes, ou mesmo adotar um ponto de partida claramente crítico, que não foi o principal intento deste artigo. Apenas como ilustração, é possível imaginar uma empreitada nesta última direção que problematize a ideologia de desenvolvimento fortemente influenciada pela modernidade industrial que perpassa todos os autores e acaba resultando em uma separação conceitual entre modernidade/tradição, que, mesmo conciliada em projetos de transformação política, acaba classificando populaçóes locais em categorias como o "indígena" e o "africano".

De qualquer maneira, ficaram evidentes as dificuldades para a transposição de um aparato conceitual nascido no contexto social europeu do século XIX para ambientes tão distintos como a América Latina - ou andina, mais especificamente - da década de 1920 e o continente africano, em plena luta por libertação colonial, entre os anos 1950 e 1960.
Buscou-se, assim, delinear a originalidade com que os autores lidaram com as particularidades locais de suas sociedades. Isso fica claro quando constatamos que nenhum dos três se filiou às diretrizes do socialismo soviético, optando por uma forma mais livre de desenvolvimento intelectual: Mariátegui expôs sua tese sobre a questão indígena num evento do próprio Comintern, enquanto Senghor e Nkrumah buscaram uma via socialista deliberadamente "não alinhada" com Moscou.

\section{Notas}

1 Antigos colonos descendentes de espanhóis.

2 Mariátegui foi pressionado pelo governo a deixar o país devido à sua participação na Greve Geral de 1918 (Miller, 2008, p. 151).

3 Na década de 1930, Senghor e Nkrumah realizaram suas formaçóes acadêmicas na França e nos Estados Unidos, respectivamente. Em seguida, trabalharam como docentes naqueles mesmos países, nas áreas de letras e filosofia.

4 Nkrumah, entretanto, não adotava a estratégia de um partido de vanguarda, que demandava uma base social mais homogênea do que seu projeto de uniáo continental permitia vislumbrar (Hountondji, 1983, 151).

5 Termo utilizado pelo autor para designar o regime de propriedade de terras "semifeudal" criollo. (Mariátegui, 2008 [1928b], caps. 1-3).

6 À época do texto citado, esse partido era o Parti de la Fédéracion Africaine (PFA), que esteve à frente da formação e da independência da Federação do Mali em 1959.

7 Comunidade formada em 1958 pelo governo De Gaule para coordenar as relaçóes entre a França e suas ex-colônias. Tratava-se de um desdobramento da Loi Cadre, passada em Paris no ano de1956, que abriu a oportunidade de independência às colônias francesas por meio de um processo pacífico.

\section{BIBLIOGRAFIA}

ANDERSON, Benedict. (2010 [2008]), Comunidades imaginadas. São Paulo, Companhia das Letras. 
CHARLES, Bernard. (1965), "Le socialisme africain: mythes et réalités". Revue Française de Science Politique, 15e. année, 5: 856-884.

DÉVES-VÁLDES, Eduardo. (2008), O pensamento africano subsaariano. Buenos Aires/Rio de Janeiro, Clacso/Ucam.

DIAGNE, Souleymane Bachir. (2007), Léopold Sédar Senghor: l'art africain comme philosophie. Paris, Riveneuve.

DOMINGUES, José Maurício. (2009), A América Latina e a modernidade contemporânea. Belo Horizonte, UFMG.

HAYA DE LA TORRE, Victor Raul. (1986 [1936]), El antimperialismo y el APRA. Lima, Fundación Navidad del Niño del Pueblo.

HOUNTONDJI, Paulin. (1983), African philosophy: myth and reality. Bloomington/Indianapolis, Indiana University Press.

LIPSET, Seymour M. (1967), "Values, education and entrepreneurship”, in S. Lipset, M. A. SOLARI, (orgs.), Elites in Latin America. Oxford, Oxford University Press.

LÖWY, Michael. (1999), "Introdução: pontos de referência para uma história do marxismo na América Latina”, in M. Löwy (org.), $O$ marxismo na América Latina. São Paulo, Fundação Perseu Abramo.

(2005), "Nem decalque, nem cópia: o marxismo romântico de José Carlos Mariáegui”, in M. Löwy, (org.), José Carlos Mariátegui: por um socialismo indo-americano. Rio de Janeiro, Editora da UFRJ.

MACAMO, Elísio. (2005), "Negotiating modernity: from colonialism to globalization", in E. Macamo, (org.), Negotiating modernity: Africa's ambivalent experience. Dakar/Londres, Codesria/Zed.

MARIÁTEGUI, José Carlos. (2005 [1924a]), "O nacional e o exótico”, in M. Löwy, (org.), José Carlos Mariátegui: por um socialismo indo-americano. Rio de Janeiro, Editora da UFRJ.

(2005 [1924b]), "A unidade da América indo-espanhola", in M. Löwy, (org.), José Carlos Mariátegui: por um socialismo indo-americano. Rio de Janeiro, UFRJ.

(2005 [1924c]), O problema elementar do Peru, in M. Löwy, (org.), José Carlos Mariá- tegui: por um socialismo indo-americano. Rio de Janeiro, Editora da UFRJ.

. (2005 [1927a]), "Indigenismo e socialismo: intermezzo polêmico", in $\mathrm{M}$. Löwy, (org.), José Carlos Mariátegui: por um socialismo indo-americano, Rio de Janeiro, Editora da UFRJ.

(2005 [1927b]), "Heterodoxia da tradição”, in M. Löwy, (org.), José Carlos Mariátegui: por um socialismo indo-americano. Rio de Janeiro, Editora da UFRJ.

(2005 [1927c]), "A tradição nacional", in M. Löwy, (org.), José Carlos Mariátegui: por um socialismo indo-americano, Rio de Janeiro, Editora da UFRJ.

. (2005 [1928a]), "Princípios programáticos do Partido Socialista", in M. Löwy, (org.), José Carlos Mariátegui: por um socialismo indo-americano, Rio de Janeiro, Editora da UFRJ.

. (2005 [1928b]), "Aniversário e balanço", in M. Löwy, (org.), José Carlos Mariátegui: por um socialismo indo-americano, Rio de Janeiro, Editora da UFRJ.

(2005 [1959]), "O determinismo marxista”, in M. Löwy, (org.), José Carlos Mariátegui: por um socialismo indo-americano, Rio de Janeiro, Editora da UFRJ.

. (2006 [1929a]), "El problema de las razas en América Latina”, in , Ideología y politica. Caracas, Ministério de Comunicación y Información.

. (2006[1929b]), "Punto de vista anti-imperialista", in Ideología y politica, Caracas, Ministério de Comunicación y Información.

(2008 [1928]), Sete ensaios de interpretação da realidade peruana. São Paulo/Buenos Aires, Expressão Popular/Clacso.

MARX, Karl \& ENGELS, Friedriech. (1998 [1848]), O manifesto comunista. São Paulo, Paz e Terra.

MILLER, Nicola. (2008), Reinventing modernity in Latin America. Nova York, Palgrave Macmillan.

MOHAN, Jitendra. (1966), "African varieties of socialism". The Socialist Register, 3: 220-265.

NKRUMAH, Kwame. (1963), Africa Must Unite. Nova York/Washington, Frederick Praeger. 
(1967 [1965]), Neocolonialismo: último

estágio do imperialismo. Rio de Janeiro, Civilização Brasileira.

. (1967), "African socialism revisited", in , Africa: national and social revo-

lution, Praga, Peace and Socialism Publishers. . (1970 [1964]), Conciencism. Nova York, Monthly Review Press.

SENGHOR, Léopold Sédar. (1956), "L’esprit de la civilisation ou les lois de la culture négro-africaine". Revue Présence Africaine, 8-10: 51-65. . (1961 [1959]), "Rapport sur la doctrine et le programme du parti”, in _, $\mathrm{Na}$ tion et voie africaine du socialisme, Paris, Présence Africaine.

(1961 [1960]), "La voie africaine du socialisme", in , Nation et voie africaine du socialisme, Paris, Présence Africaine. . (1961), "Avant-propos", in

Nation et voie africaine du socialisme. Paris, Présence Africaine. . (1977 [1966a]), "Qu'est-ce que la négritude?", in , Liberté I, Paris, Seuil. . (1977 [1966b]), "La négritude est un humanisme du XXe. siècle", in , $L i-$ berté I, Paris, Seuil. . (1977 [1970]), "Négritude et modernité ou la négritude est un humanisme du XXe. Siècle", in , Liberté I, Paris, Seuil. 


\section{Socialismo, modernidade e identidade regional em Mariátegui, Senghor e Nkrumah}

\section{Fabrício Cardoso de Mello}

Palavras-chave: Socialismo; Modernidade; Identidade; Pensamento social e político; Periferia global.

Este artigo pretende oferecer uma contribuição ao estudo comparativo do pensamento social e político elaborado desde a periferia global. Ao traçar paralelos e apresentar pontos de desacordo, o objetivo é analisar os pensamentos de José Carlos Mariátegui, Léopold Sédar Senghor e Kwame Nkrumah, com o argumento de que suas trajetórias enquanto intelectuais engajados politicamente na periferia global levaram-nos a enfrentar desafios teóricos bastante próximos. Três questôes são apresentadas como chaves para a realização desta empreitada, devido à posição central que ocupam nas obras dos autores: um projeto de emancipação fundado no socialismo, uma ideia de modernidade que se articula com elementos societários pré-coloniais da América Latina e da África e a necessidade de uma identidade regional que oferecesse um senso de comunidade alternativo aos impostos pelo colonialismo. Esses elementos serão discutidos ao longo das três seçóes que estruturam o texto.

\section{Socialism, Modernity and Regional Identity in Mariátegui, Senghor and Nkrumah}

\section{Fabrício Cardoso de Mello}

Keywords: Socialism; Modernity; Identity; Social and political phought; Global periphery.

This article offers a contribution to the comparative study of social and political thought elaborated in the global periphery. By tracing parallels and exploring divergent positions, the objective is to analyze the thought of José Carlos Mariátegui, Léopold Sédar Senghor e Kwame Nkrumah, arguing that their trajectories as politically committed intellectuals in the global periphery brought to them similar theoretical challenges. Three main issues are presented as keys for such comparison, given their centrality in each of the authors' work: a project of emancipation based on socialism, an idea of modernity that is articulated with pre-colonial societal elements from Latin America and Africa, and the necessity of a regional identity that served as base for a sense of community alternative to the colonial legacy. These elements will be discussed along the three sections that structure the text.
Socialisme, modernité et identité régionale en Mariátegui, Senghor et Nkrumah

\section{Fabrício Cardoso de Mello}

Mots-clés: Socialisme; Modernité; Identité; Pensée sociale et politique; Péripherie globale.

Cet article se propose d'offrir une contribution à l'étude comparative de la pensée sociale et politique développée depuis la périphérie globale. En traçant des parallèles et des lignes de divergence, l'objectif est d'analyser les pensées de José Carlos Mariátegui, Léopold Sédar Senghor et Kwame Nkrumah, avec l'argument que leur carrière tant qu'intellectuels politiquement engagés dans la périphérie mondiale les ont conduit à relever les défis théoriques très proches. Trois questions sont présentées comme les clées de la réalisation de ce projet, en raison de la position centrale qu'ils occupent dans les œuvres des auteurs: un projet d'émancipation fondé dans le socialisme, une idée de la modernité qui se connecte avec des éléments sociétaux pré-coloniales d'Amérique latine et d'Afrique et la nécessité d'une identité régionale qui offre un sentiment de communauté alternative à celle imposée par le colonialisme. Ces éléments seront discutés tout au long des trois sections qui structurent le texte. 